\title{
PROPOSAL PENAWARAN \\ JASA PEMBUATAN APLIKASI START UP
}

(Start Up Application For Business)

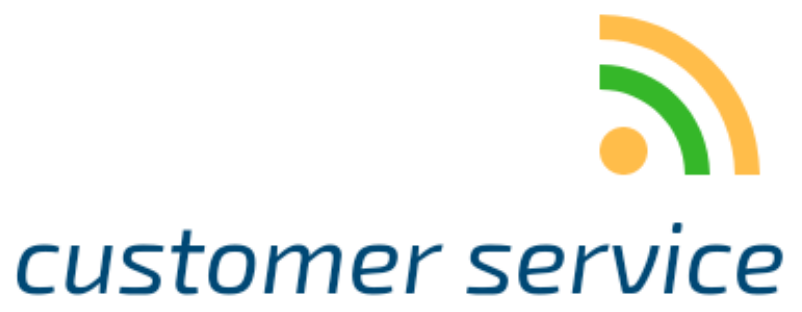

TEKNOLOG I INFORMAS I

\author{
NAMA : PRIA MITRA PURBA \\ NIM : 0702201004
}

KELAS : SISTEM INFORMASI 4

MATA KULIAH : SISTEM INFORMASI MANAJEMEN DOSEN PENGAMPU : Dr.YAHFIZAM,S.T.,M.Cs.

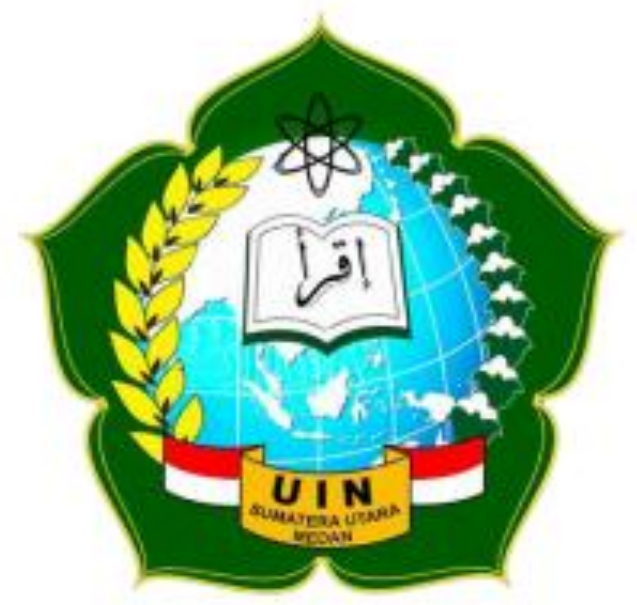

FAKULTAS SAINS DAN TEKNOLOGI UNIVERSITAS ISLAM NEGERI SUMATERA UTARA TAHUN 2021 


\section{CUSTOMER SERVICE IT}

Menerima Jasa Pembuatan Aplikasi Start Up Seperti : Ojek Online \& Online Shop Alamat : Jl.Karya Amal No 17,Kel.Pangkalan Mahsyur,Kec.Medan Johor,Kota Medan Email : priamitrapurba27@gmail.com Wa : 0821-8413-1628 Ig : @customer_service_it

Lampiran : 1 (satu) set Proposal

Perihal : Penawaran Pembuatan Aplikasi Start Up

Kepada Yth.

Bapak/Ibu Pimpinan PT COKELAT GAUL

Di Tempat

Dengan Hormat,

Sebelumnya kami mengucapkan ribuan terima kasih kepada bapak/ibu yang telah menerima serta meluangkan waktu untuk membaca proposal penawaran ini, sehingga bapak/ibu dapat mempertimbangkan dan memilih beberapa produk jasa yang kami tawarkan.

Kami dari CUSTOMER SERVICE IT merupakan salah satu developer pengembangan aplikasi start up yang bergerak di bidang bisnis dan kewirausahaan. CUSTOMER SERVICE IT lebih menitikberatkan ke pengembangan aplikasi start up seperti Ojek Online dan Online Shop. Dalam hal ini kami bergerak dalam rangka untuk membangkitkan perekonomian khususnya dimasyarakat kita saat ini dan terlebih lagi dimasa covid 19 seperti ini. Di harapkan dengan adanya Aplikasi Start Up ini nantinya dapat meningkatkan minat pengunjung untuk membeli produk atau jasa yang anda tawarkan sesuai harapan.

Melalui proposal penawaran ini, kami menawarkan perancangan serta design aplikasi start up untuk perusahaan yang anda pimpin saat ini, adapun produk jasa perancangan proses pembuatan aplikasi start up yang kami tawarkan telah terlampir dalam proposal ini.

Atas perhatian dan kerjasamanya, kami ucapkan terima kasih.

Medan,14-07-2021

Hormat Kami,

\section{DTO}

(PRIA MITRA PURBA)

DIREKTUR CUSTOMER SERVICE IT 


\section{A. PENDAHULUAN}

Di era zaman globalisasi ini kemajuan Teknologi Informasi sangatlah pesat, informasi dapat kita ketahui dengan mudah seiring perkembangan zaman. Dalam perkembangan teknologi saat ini memulai bisnis tidak semudah apa yang anda bayangkan. Kita lihat saja banyak saat ini pengusaha pengusaha yang kesuksesannya sangat luar biasa sehingga dapat meningkatkan perekonomian dunia. Kita tahu bahwa persaingan dalam memulai bisnis di era saat ini sangat banyak. Banyak perusahaan perusahaan yang mecari beragam cara dan ide untuk memajukan usahanya.

Saat ini berdagang atau memulai bisnis dengan aplikasi start up semakin berkembang pesat, bahkan yang kita saksikan saat ini banyak perusahaan yang sudah sukses dalam mengembangkan bisnis ini. Salah satu perusahaan start up yang sudah sukses saat ini contoh nya: Shopee,Lazada,Gojek,Grab dan lain sebagai. Aplikasi tidak hanya dapat digunakan oleh perusahaan atau lembaga besar saja melainkan semua kalangan, terutama kalangan kecil da menengah dapat menggunakan aplikasi sebagai media promosi yang hemat sekaligus menampilkan profesionalitas aplikasi menjadi salah satu media yang dapat diandalkan.

Selain itu kebutuhan aplikasi start up sudah menjadi kebutuhan penting bagi perusahaan, bahkan masyarakat menengah kebawah juga banyak yang menggunakan aplikasi start up terutama dalam berbelanja,mencari informasi,melengkapi segala kebutuhan hingga memberikan peluang bisnis yang sangat besar bagi para investor maupun pengguna. Selain itu, dengan adanya aplikasi start up ini akan menambah keuntungan yang sangat besar untuk perusahaan dalam mengembangkan bisnis. Disamping konfigurasinya sangatlah mudah, perusahaan akan semakin terbantu dan lebih efektif juga efesien. Dengan demikian perusahaan ataupun lembaga yang memiliki aplikasi start up sendiri cenderung di anggap lebih bonafid, sementara iklan di media massa,kop surat,sampai kartu nama usaha mencantumkan nama perusahaan di dalam aplikasi cenderung dinilai lebih berbobot dan lebih profesional.

Dengan ini, kami CUSTOMER SERVICE IT yang bergerak dalam bidang Teknologi Informasi dan Program serta design aplikasi menawarkan sebuah bentuk kerjasama kepada bapak atau ibu sebagai perusahaan, Organisasi ataupun personal dalam memanfaatkan media aplikasi sebagai pilihan bijaksana untuk mengembangkan potensi sekaligus sarana untuk memperkenalkan (promosi) bisnis yang akan dijalankan kepada seluruh dunia. Bersama anda, kami akan mencoba untuk membangun sebuah aplikasi start up dengan gambaran anda dan memiliki tujuan, serta memenuhi target yang dicanangkan. Bagaimana sebuah bisnis atau usaha tidak mati dan banyak dikunjungi orang dari waktu kewaktu serta menambah peminat orang untuk menggunakan aplikasi yang dibuat, serta dapat meningkatkan keuntungan dan perekonomian perusahaan secara drastis. Dengan adanya aplikasi start up yang akan kami buat nantinya bisnis bapak/ibu in syaa allah akan sangat berkembang pesat. Dikarenakan angka peminat masyarakat dalam berbelanja,membeli ataupu memenuhi kebutuhannya sehari hari, cukup menggunakan aplikasi dalam medianya, barang ataupun keinginan nya langsung terpenuhi. 


\section{MENGAPA HARUS APLIKASI START UP?}

Aplikasi start up memberikan solusi bagi dunia usaha guna menjangkau konsumen sebanyak mungkin dimana saja dan kapan saja, tidak terbatas wilayah geografi dan waktu. Selain dapat diakses dimana dan kapan saja, aplikasi start up seperti online shop sangat praktis digunakan dan sangat mudah tentunya. Pengguna hanya tinggal mendownload di play store dan aplikasi siap digunakan. Dengan adanya aplikasi start up belanja ataupun memenuhi kebutuhan jadi sangat mudah, tinggal pesan, lalu notif masuk kemudian di proses lalu dikirimkan, dan tentunya ada prosedur prosedur khusus dalam menjalankannya.

Hal ini sangat menguntungkan perusahaan dan konsumen karena perusahaan dapat menjelaskan maupun memasarkan produk/jasa secara terperinci dan mudah. Konsumen akan mendapatkan keterangan secara detail dan terperinci, dan jika konsumen tertarik dengan produk/jasa yang ditawarkan maka konsumen tinggal memesan via aplikasi saja. Hal ini dapat dilakukan cepat,tepat,kapan saja dan dimana saja.

\section{BEBERAPA ALASAN MENGAPA HARUS MEMILIKI APLIKASI START UP SENDIRI}

1. Meningkatkan jangkauan promosi,dengan memiliki aplikasi start up maka produk/jasa akan lebih banyak dikenal masyarakat bahkan sampai ke mancanegara.

2. Aplikasi start up sangat praktis digunakan, sehingga konsumen dapat dengan mudah mengakses kapan saja dan dimana saja.

3. Dengan memiliki aplikasi start up berrati sama saja memiliki karyawan yang mempromosikan serta menjajakan produk/jasa kita selama 24 jam sehari dan 7 hari seminggu.

4. Sebagai media untuk memperkenalkan dan menjual produk/jasa perusahaan atau bisnis kepada konsumen atau masyarakat umum.

5. Aplikasi merupakan media promosi sekaligus media penjualan yang menawarkan biaya yang terjangkau dan efesien jika dibandingkan dengan media lainnya.

6. Anda dapat memiliki aplikasi start up sendiri tanpa harus memiliki kantor/perusahaan, sehingga dapat menjalankan bisnis atau usaha walau dari rumah sekalipun.

7. Dengan design yang profesional dan eksklusif dapat menarik minak dan kepercayaan konsumen dalam membeli produk/jasa yang ditawarkan.

8. Keuntungan berjualan berlipat ganda, bahkan dapat memberikan keuntungan yang sangat fantastis dibanding dengan berjualan offline.

9. Aplikasi start up juga cocok untuk bisnis rumahan, dan bisnis kecil kecilan.

10. Peluang pembeli/konsumen sangat besar. 


\section{JENIS PAKET DAN BIAYA LAYANAN}

\section{A. BUSINESS PRAKTIS (For Bisnis)}

Paket bisnis praktis sangat cocok digunakan bagi anda yang memiliki usaha menengah keatas atau yang sudah memiliki usaha sebelumnya yang sudah lumayan berkembang tetapi ingin meningkatkan omset yang lebih besar lagi. Fasilitas yang diberikan serta biaya jenis paket ini meliputi :

\section{BIAYA OPERASIONAL}

\section{Rp 1599.000}

\section{FASILITAS}

Akses domain aplikasi selama 6 bulan, setelah itu membayar biaya domain per bulan sebesar Rp.100.000,-

$>$ Akses server penyimpanan maksimal upload produk sebanyak 5000 produk

$>$ Unlimited lokasi pengiriman dan slide utama.

> Mendapatkan akses aplikasi khusus admin, aplikasi yang diberikan akan ada 2 aplikasi, yang pertama aplikasi khusus admin/perusahaan dan yang kedua aplikasi khsusus konsumen.

$>$ Mendapatkan bimbingan khusus melalui wa/telegram

$>$ Upload gambar/produk sendiri dengan mudah maksimal 7 gambar setiap 1 produk.

$>$ Konfirmasi email pendaftaran setiap konsumen langsung ke email member/perusahaan.

$>$ Memiliki widget dan tampilan yang sangat menarik.

$>$ Design aplikasi dapat di request dan dapat mengubah tampilan maksimal 3 kali setelah design selesai.

$>$ Unlimited push notifikasi via aplikasi admin, aplikasi admin dan konsumen akan sama sama terhubung.

$>$ Kualitas gambar yang diberikan HD dan sangat bagus.

$>$ Judul email atas nama toko/bisnis anda.

$>$ Verifikasi nomor telepon member.

$>$ Kualitas terjamin, aplikasi anda kami akan promosikan di social media.

$>$ Upload Google Play Store dan akses google play console. 


\section{B. PRO PRAKTIS (For Pro/Menengah)}

Paket layanan PRO PRAKTIS sangat cocok digunakan buat kalangan usaha menengah yang memiliki usaha menengah sekaligus untuk meningkatkan konsumen dan menambah omset perusahaan/pembisnis/pengusaha. Fasilitas yang diberikan serta biaya jenis paket ini meliputi :

\section{BIAYA OPERASIONAL}

\section{FASILITAS}

Akses domain aplikasi selama 4 bulan, setelah itu membayar biaya domain per bulan sebesar Rp.85.000,-

> Akses server penyimpanan maksimal upload produk sebanyak 1000 produk

$>$ Unlimited lokasi pengiriman dan slide utama.

> Mendapatkan akses aplikasi khusus admin, aplikasi yang diberikan akan ada 2 aplikasi, yang pertama aplikasi khusus admin/perusahaan dan yang kedua aplikasi khsusus konsumen.

$>$ Mendapatkan bimbingan khusus melalui wa/telegram

$>$ Upload gambar/produk sendiri dengan mudah maksimal 7 gambar setiap 1 produk.

$>$ Konfirmasi email pendaftaran setiap konsumen langsung ke email member/perusahaan.

$>$ Memiliki widget dan tampilan yang sangat menarik.

$>$ Design aplikasi dapat di request dan dapat mengubah tampilan maksimal 2 kali setelah design selesai.

$>$ Unlimited push notifikasi via aplikasi admin, aplikasi admin dan konsumen akan sama sama terhubung.

$>$ Kualitas gambar yang diberikan standart/biasa.

$>$ Kualitas terjamin, aplikasi anda kami akan promosikan di social media.

> Upload Google Play Store dan akses google play console. 


\section{LITE PRAKTIS (For LITE/Basic)}

Paket layanana ini sangat cocok buat anda yang ingin memulai bisnis usaha baru atau memulai dengan bisnis kecil kecilan yang ingin memiliki omset yang lumayan dan bisa memberikan penghasilan baru buat anda. Dan harganya juga lebih murah dari paket paket sebelumnya. Fasilitas yang diberikan serta biaya jenis paket ini meliputi :

\section{BIAYA OPERASIONAL}

\section{FASILITAS}

Akses domain aplikasi selama 3 bulan, setelah itu membayar biaya domain per bulan sebesar Rp.50.000,-

$>$ Akses server penyimpanan maksimal upload produk sebanyak 200 produk

$>$ Unlimited lokasi pengiriman dan slide utama.

> Mendapatkan akses aplikasi khusus admin, aplikasi yang diberikan akan ada 2 aplikasi, yang pertama aplikasi khusus admin/perusahaan dan yang kedua aplikasi khsusus konsumen.

$>$ Mendapatkan bimbingan khusus melalui wa/telegram

$>$ Upload gambar/produk sendiri dengan mudah maksimal 7 gambar setiap 1 produk.

$>$ Konfirmasi email pendaftaran setiap konsumen langsung ke email member/perusahaan.

$>$ Memiliki tampilan yang sangat menarik.

$>$ Design aplikasi dapat di request dan dapat mengubah tampilan maksimal 1 kali setelah design selesai.

$>$ Memiliki 6 widget tampilan menarik.

$>$ Kualitas gambar yang diberikan standart/biasa.

$>$ Kualitas terjamin, aplikasi anda kami akan promosikan di social media.

$>$ Upload Google Play Store dan akses google play console.

\section{SERVICE PEMELIHARAAN DAN UPDATING APLIKASI}

$\checkmark$ Pembaharuan aplikasi maksimal 3 kali

$\checkmark$ Update play store khusus lite maksimal 4 kali karena tidak akun sendiri.

$\checkmark$ Pemeliharaan dan pengecekan aplikasi setiap 1 bulan sekali.

$\checkmark$ Keamanan dan service aplikasi terjamin.

\section{Rp 850.000}




\section{KESEPAKATAN LAYANAN KAMI :}

Calon Klien CUSTOMER SERVICE IT wajib membaca serta memahami syarat dan ketentuan sebelum memutuskan untuk menggunakan jasa CUSTOMER SERVICE IT, Sebaliknya anda harus tetap menyetujui perjanjian ini selama anda menjadi client kami.

Perjanjian ini dibuat sedemikian rupa demi kepentingan bersama, juga demi keamanan dan keleluasaan pelanggan dalam menggunakan produk/jasa CUSTOMER SERVICE IT.

Perjanjian ini juga telah dilampirkan pada form pemesanan CUSTOMER SERVICE IT dan harus di setujui pelanggan. Dokumen ini dapat berubah sewaktu waktu sesuai kebutuhan.

\section{SYARAT DAN KETENTUAN LAYANAN}

1.Wajib memberikan nama lengkap,alamat,alamat email yang jelas dan valid serta informasi lainnya yang dibutuhkan.

2. Calon klient wajib mengisi formulir yang sudah disediakan secara online dan wajib mengunggah data yang diperlukan.

3. Ubah design dilakukan sesuai ketentuan paket layanan yang diambil.

4. Masa aktif aplikasi selama waktu yang ditentukan sesuai paket layanan. Jika melewati batas klient harus melakukan perpanjangan domain aplikasi sesuai paket yang telah dipilih. Jika tidak maka kami akan melakukan pen non aktifan aplikasi secara otomatis.

5. Kami tidak bertanggung jawab atas isi/produk serta transaksi yang di tawarkan didalam aplikasi, sepenuhnya tanggung jawab klient.

6. Aplikasi tidak melanggar hukum dan UU (Pornografi,aktivitas ilegal,dll) kami berhak menghentikan layanan atau menghapus layanan apabila pelanggaran dilakukan tanpa pemberitahuan.

7. Dengan memesan jasa pembuatan aplikasi di CUSTOMER SERVICE IT, berarti client setuju dengan syarat dan ketentuan layanan diatas. 


\section{LAMPIRAN APLIKASI YANG KAMI BUAT :}
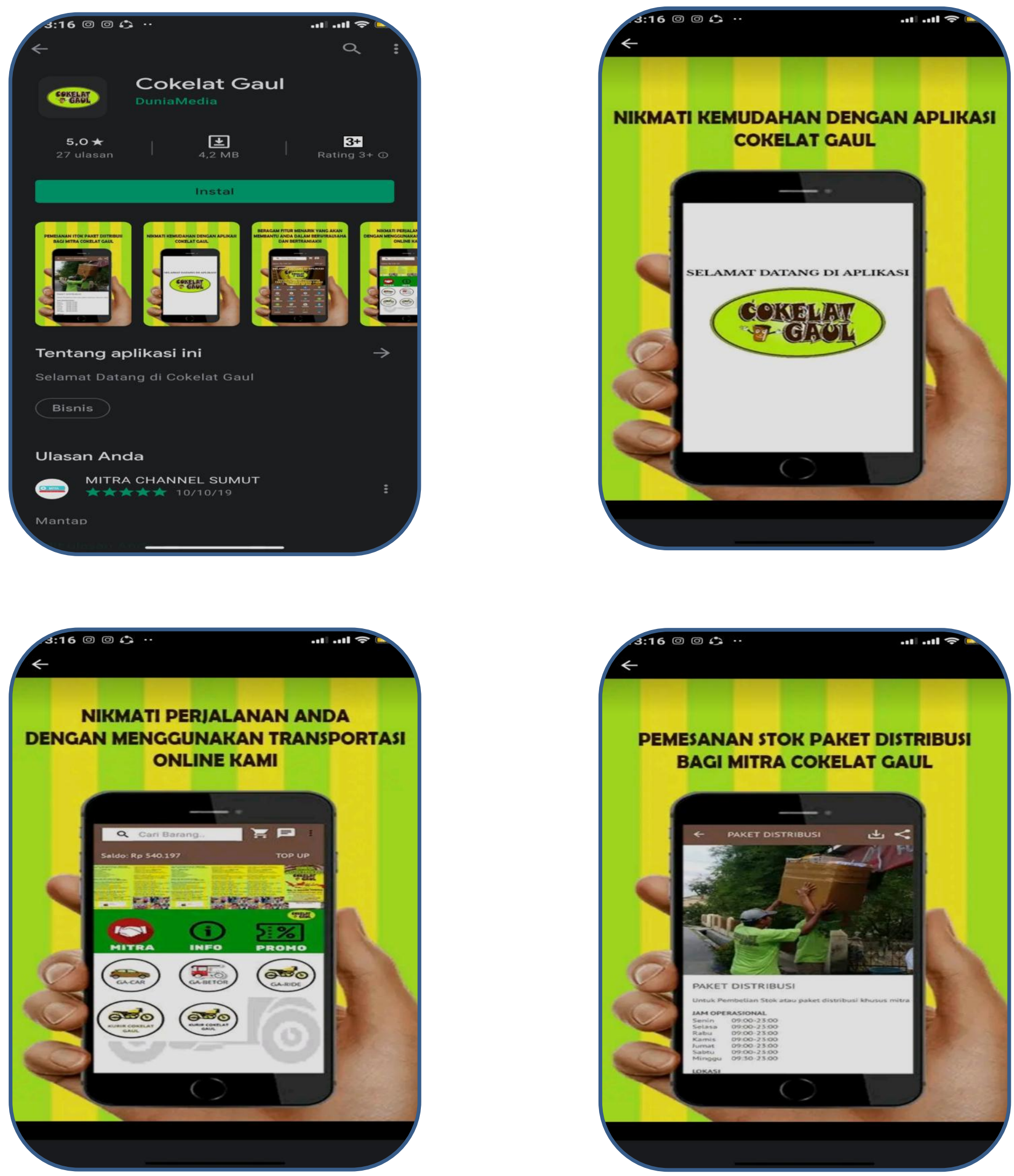